\title{
Habitat Characteristics Modelling Dendrocygna javanica (Horsfield, 1821) in North Sumatera, Indonesia, using GIS (Geographic Information System)
}

\author{
Lazuardi $^{1}$, Puji Prastowo ${ }^{2}$, etcWasis Wuyung Wisnu Brata ${ }^{3}$,Eko Prasetya ${ }^{4}$ \\ \{drslazuardi@gmail.com, prast71@gmail.com,wasisbrata@unimed.ac.id, \\ ekoprasetya.biologi@gmail.com\}
}

Department Biology, Faculty of Mathematics and Natural Science, Universitas Negeri Medan, Jl. Willem Iskandar, Pasar V, Medan, North Sumatera, Indonesia ${ }^{1,2,3,4}$

\begin{abstract}
Dendrocygna javanica (Horsfield, 1821) is a member of the family Anatidae, the order of Anseriformes, class of Aves, phylum Chordata, of kingdom Animalia. This species is commonly called the Lesser Whistling-duck because it flies in a noisy sound. In Indonesia, it is known as Belibis Batu. Dendrocygna javanica is spread in the regions of Asia including Indonesia. In Indonesia, D. javanica is spread on the islands of Sumatra, Kalimantan, Java, East Nusa Tenggara and West Nusa Tenggara. This study aims to create a distribution model of Dendrocygna javanica based on habitat characteristics in North Sumatra, Indonesia, using GIS (Geographic Information System). A total of 35 distribution points of D. javanica in 8 districts in North Sumatra were analyzed using ArcGis 10.3 software to analyze habitat characteristics. The results showed that D. javanica spread on habitat characteristics Rainfall ranged from 1500-3500 $\mathrm{mm} /$ year, 5 soil types namely ferric acrisols (4 points), humic acrisols (4 points), dystric cambisols ( 2 points), orthic ferrasols (5 point), and dystric fluvisols (20 points), 7 types of land cover namely dryland forest ( 2 points), plantation ( 5 points), dryland agriculture (10 points), rice fields ( 2 points), swamp (4 points), plus ( 4 points), and body of water ( 8 points), and are at an elevation of 3-1072 meters above sea level. Dendrocygna javanica is spread in a limited area. This research is expected to be an important source of information in the conservation of D. javanica in North Sumatra
\end{abstract}

Keywords: Dendrocygna javanica, ArcGis 10.3, Habitat Characteristic, Geographic Information System

\section{Introduction}

The population growth rate in Indonesia reached $1.49 \%$ in 2010 with a population of 237,641,326 people (BPS, 2010). The high frequency and amount of population growth in Indonesia also influence the high level of food needs (Prabowo, 2011). Increasing food needs result in massive exploitation of natural resources to meet primary needs (Sutanto, 2002). Large-scale exploitation of natural resources and not paying attention to conservation aspects will cause environmental damage and scarcity of some types of individuals due to loss to forest functions (Frissell and Bayles, 1996).

Poultry is one of the potential food sources in Indonesia. Poultry is a good producer of animal protein for consumption by the community (Rasyaf, 2012). Domesticated poultry is divided into two types, namely waterfowl and landfowl. The difference can be marked based 
on the shape of the claws where in land birds, the claws form separate fingers while in waterfowl has a swimming membrane that connects each of his fingers.

National poultry contribution to meat availability reaches $1,335,143$ tons or $64.46 \%$ of the total domestic meat availability. The need for meat as a source of protein is increasing along with the increase in population, so a breakthrough in the search for wild animals that has the potential to be an alternative to meat is needed (Baskoro, 2009). Exploration and domestication of wild animals can be used as a source of food, increasing income and the need for animal protein so that it is necessary to preserve and burn certain types of animals (Hardjosubroto, 1994).

The status of the quibble at the IUCN (International Union for Conservation of Nature) is the Least Concern where this species has a large enough number so that it is not close to the susceptible threshold even though it tends to decrease or very fragmented population size (Birdlife International, 2016). Whistling duck is one of the birds that have a habitat closer to water with the ability to swim in the water so that mobility activities in terrestrial areas are very rare, and are only used to find food, avoid opponents, and lay eggs (Ansari, et al., 2017).

Whistling duck in Indonesia is spread over the islands of Borneo, Sumatra, and Java (Birdlife International, 2016). People in Kalimantan have long been consuming whistling duck as food. Sale of whistling duck in Kalimantan has begun to be monitored because the community obtained it by hunting unattended. In 2004, around 120,000 - 165,000 whistling duck were captured in the Mahakam Lake of East Kalimantan, and 95\% of that amount was marketed in Banjarmasin (Siwi, et al., 2011).

Whistling duck belongs to the genus Dendrocygna, order Anseriformes, and family Anatidae (Hoyo et al., 2014). In Indonesia, there are two types of whistling duck, which are belibis kembang (Dendrocygna acuarta) and belibis batu (Dendrocygna javanica). Anseriformes are orders consisting of 150 species and show very high diversity throughout the world (Olson and Feduccia, 1980).

In Indonesia, data and information about whistling duck are still very limited. This is because the lack of research on the types of whistling duck in Indonesia has become a separate obstacle when it comes to cultivating whistling duck as a food source as well as in determining the whistling duck conservation strategy. The purpose of this study was to analyze the character of whistling duck habitat in North Sumatra using the GIS (Geographic Information System) approach. The results of this study are expected to be important information in the effort to conserve whistling duck in North Sumatra..

\section{Materials and methods}

The main text should be written using Times New Roman, 10pt, fully justified. Italics can be used for emphasis and bold typeset should be avoided.

\subsection{Collecting coordinate points}

Collecting sample coordinates is carried out throughout the North Sumatra region which is the Whistling duck distribution site. Coordinate taking is done using the GPS (Global Position System) Garmin Etrex 30 type. The sampling area included 9 locations, namely Central Tapanuli, Mandailing Natal, Medan, Deli Serdang, Langkat, Serdang Bedagai, Asahan and Siantar. The sampling area is presented in Table 1. 


\section{2parameters}

The parameters analyzed in this study consisted of parameters of soil type, rainfall, altitude, and type of land cover. These parameters are obtained from various geographic data sources (Table 2). The choice of parameters is based on the character of the habitat whistling duck based on the reference.

\section{3analysis data}

Data analysis was performed by the scoring method based on the coordinate layout with geographic parameter maps using ArcGis 10.3 application. Scoring results in the form of habitat characters were then analyzed to see the most dominant characters. Visualization of the results of the data is made in the form of habitat maps based on the parameters used.

Table 1.D. javanica coordinate region in North Sumatra

\begin{tabular}{lll}
\hline No & Regency & Total \\
1 & Central Tapanuli & 5 \\
2 & Mandailing Natal & 4 \\
3 & Medan & 7 \\
4 & Langkat & 5 \\
5 & Deli Serdang & 2 \\
6 & Tebing Tinggi & 3 \\
7 & Tanjung Balai & 2 \\
8 & Asahan & 1 \\
9 & Siantar & 6 \\
\hline
\end{tabular}

Tabel 2. Source of parameter data used in the analysis

\begin{tabular}{lll}
\hline No & Parameter & Source \\
1 & Soil Type & FAO UNESCO Soil Map of Southeast Asia, 2003 \\
2 & Rainfall & $\begin{array}{l}\text { Indonesian Agency for Meteorological, } \\
\text { Climatological and Geophysics (BMKG) }\end{array}$ \\
3 & Elevation & $\begin{array}{l}\text { DIVA-GIS (Hijmans, et al., 2004) } \\
\text { Directorate General of Forestry Planning, Ministry } \\
\text { of Forestry Indonesian Repoblic of Indonesia }\end{array}$ \\
\hline
\end{tabular}

\section{Result and discussion}

Source of parameter data used in the results showed that D. javanica spread in areas with rainfall of 1500-3500 mm/year (Figure 1). According to Ansari et al. (2017), D. javanica is more like a land that is wet with fresh air because of guaranteed food rises. D. javanica habitat helps in areas that are wet with shrub plants that are high enough to protect it during the daytime during the daytime, D. javanica will actively forage (Ali and Ripley, 1983). 


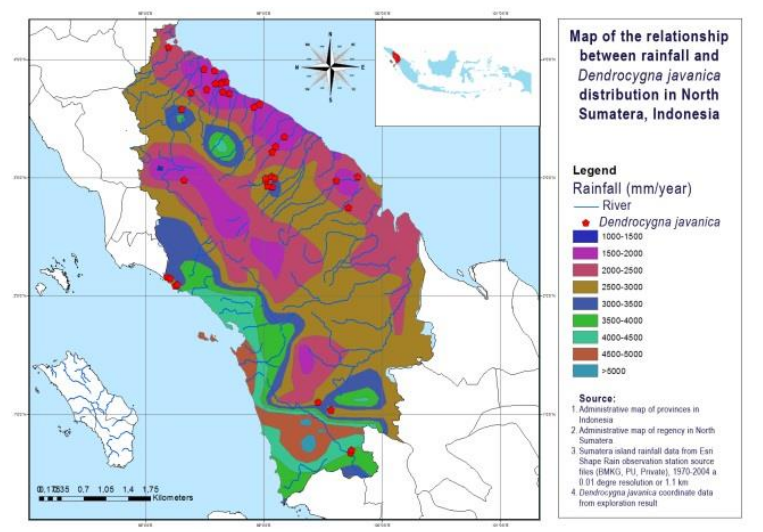

Fig. 1: Rainfall characteristics on the distribution of D. javanica

According to Renade, et al. (2017), D. javanica is a species commonly found in the lowlands and wetlands in the Southeast Asian region. The results showed that D. javanica was spread in wet areas such as water bodies, ponds, swamps, and rice fields $(51.4 \%)$, although some were found in dry areas such as dryland forests, plantations, and dryland agriculture (48.6\%) (Figure 2). This result is following the results of the study of Rajpar and Zakaria (2011) which stated that D. javanica is a species found mostly in swamps. Some countries with highlands in Southeast Asia are also inhabited by D. javanica, for example, Nepal. In Nepal, a portion of D. javanica lives in the highlands where the land remains wet. This is following the results of research showing that D. javanica is found at an altitude of 2-324 meters above sea level (Figure 3)

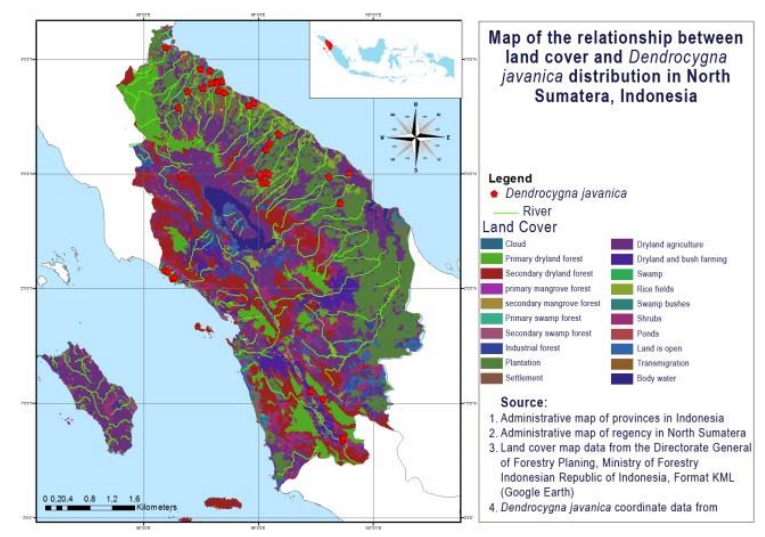

Fig. 2: Landcover characteristics on the distribution of $D$. javanica 


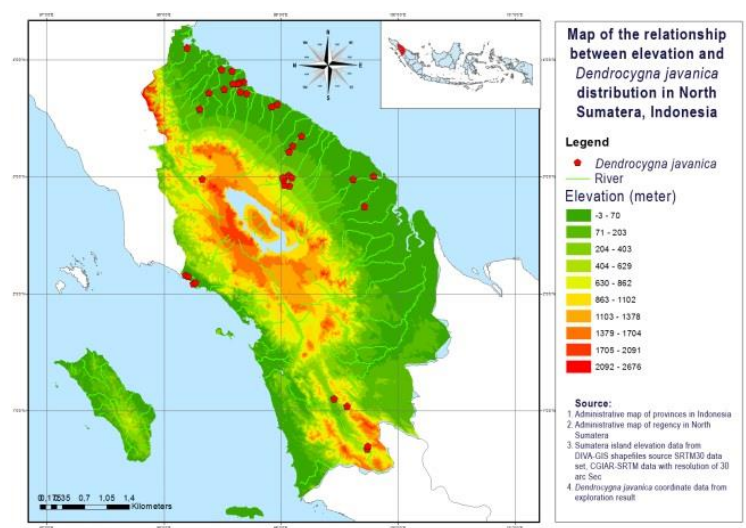

Fig. 3: Elevation charasteristics on the distribution of D. javanica

Dendrocygna javanica is usually found in territorial waters with small areas and agriculture but is very sensitive to human existence (Baral, 2009). The presence of humans that is quite disturbing can cause these animals to move to a quieter place with adequate food supplies. This result also showed D. javanica to like areas covered by tall bushes.

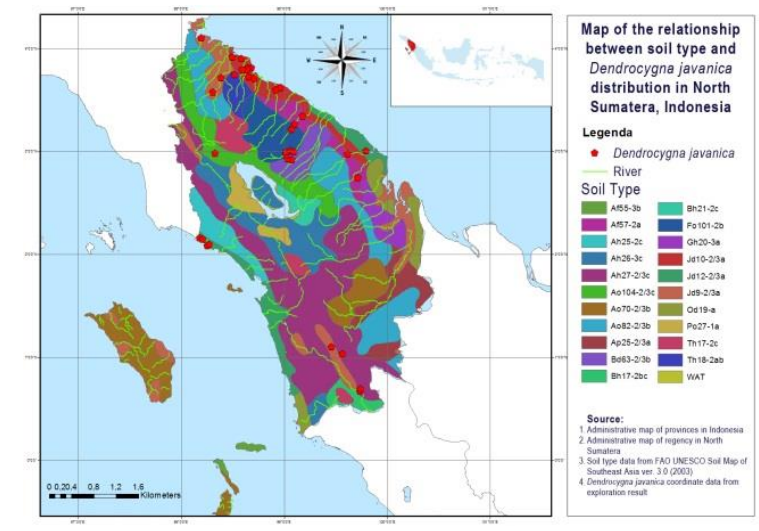

Fig 4: Soil type charasteristics on the distribution of $D$. javanica

The results showed that the dominant soil type as the distribution area of D. javanica was Distric Fluvisols (Figure 4). Distric Fluvisols are land that is regularly submerged in water and still in swamp forests, along with the coast, and mangrove vegetation. Distric Fluvisols are generally found in Sumatra, Java, Kalimantan, Irian Jaya, Sulawesi, and Maluku (FAO, 1979).

\section{Conclusions}

Habitat characteristics Dendrocygna javanica is wetland in the lowlands or highlands, rainfall 1500-3500 meters/year, Dystric Fluvisols soil types, height 3-324 meters above sea 
level, and land cover in the form of dryland agriculture, water bodies, ponds, swamps, rice fields, and plantations.

Acknowledgements. The author is very grateful to the Indonesian Minister of Research, Technology and Higher Education for his support in the form of research funding in the Higher Education Foundation Basic Research scheme, 2018 funding year

\section{References}

[1]Rasyaf, M., 2012. Panduan beternak ayam pedaging. Niaga Swadaya. Depok

[2]BPS, 2010. Results of the Indonesian Population Census 2010. Accessed on May 25, 2017

[3]Prabowo, R., 2010. Kebijakan Pemerintah Dalam Mewujudkan Ketahanan Pangan Di Indonesia. Mediagro, 6(2)

[4]Sutanto, R., 2002. Pertanian organik: Menuju pertanian alternatif dan berkelanjutan. Kanisius. Yogyakarta

[5]Frissell, C.A. and Bayles, D., 1996. Ecosystem Management and The Conservation of Aquatic Biodwersity and Ecological Integrity 1. JAWRA Journal of the American Water Resources Association, 32(2), pp.229-240.

[6]Baskoro, K. 2009. Semarang Bird Web. Semarang Bird Community. Semarang

[7]BirdLife International 2016. Dendrocygna javanica. The IUCN Red List of Threatened Species 2016: $\quad$ e.T22679758A92828691.http://dx.doi.org/10.2305/IUCN.UK.20163.RLTS.T22679758A92828691.en

[8]Hardjosubroto, W. 1994. Aplikasi pemuliabiakan ternak di lapangan. Penerbit PT. Gramedia Widiasarana Indonesia, Jakarta

[9]Ansari, SV., Sathick, O., Akshad, A., Muthukumaravel, K. 2017. Present status of lesser whistling duck (Dendrocygna javanica) among the total avian species at Mavoor wetland, Kerala, South India. International Journal of Zoology and Applied Biosciences 2 (1): 32-37

[10]Siwi, N., Wahyuni, TH, Hamdan. 2014. Identifikasi Morfologi dan Morfometri Organ Pencernaan Serta Sifat Kualitatif Warna Bulu Belibis Kembang (Dendrocygna arcuata) dan Belibis Batu (Dendrocygna javanica). J. Peternakan Integratif 2. (2): 193-208

[11]Olson SL, Feduccia A. 1980. Presbyornis and the origin of the Anseriformes (Aves: Charadriomorphae). Zoology 323: 1-24.

[12]Del Hoyo, J., Collar, N.J., Christie, D.A., Elliott, A. and Fishpool, L.D.C. 2014. HBW and BirdLife International Illustrated Checklist of the Birds of the World. Lynx Edicions BirdLife International

[13]Hijmans, R.J., Guarino, L., Bussink, C., Mathur, P., Cruz, M., Barrentes, I. and Rojas, E., 2004. DIVA-GIS. Vsn. 5.0. A geographic information system for the analysis of species distribution data. Manual available at. http://www.diva-gis.org

[14]Rajpar, M.N. and Zakaria, M., 2011. Bird species abundance and their correlationship with microclimate and habitat variables at Natural Wetland Reserve, Peninsular Malaysia. International Journal of Zoology, 2011

[15]Ali, S. and Ripley, S.D., 1983. Handbook of the birds of India and Pakistan (compact edition). Oxford University Press and BNHS, Mumbai

[16]Ranade, S. P., \& Prakash, V. (2016). Nesting of Lesser Whistling-Duck Dendrocygna javanica (Horsfield, 1821) (Aves: Anseriformes: Anatidae) and broken-wing distraction display at Kamrup District, Assam, India. Journal of Threatened Taxa, 8(5), 8824-8826.

[17]Baral, H. S. 2009. Updated status of Nepal's wetland birds. Banko Janakari, 19(3), 30-35.

[18]FAO, 1979. Soil Map of the World, 1 : 5,000,000. Vol. 1, legend. Unesco-Paris 